\title{
Beyond Seattle: globalization, the nonmarket environment and corporate strategy ${ }^{1}$
}

\author{
Aseem Prakash
}

The George Washington University

\begin{abstract}
Globalization is changing MNEs' nonmarket environments in four ways. First, instead of a 'retreat' of the state across sectors, it is leading to deregulation as well as reregulation. Because cross-border mergers and acquisitions are creating global oligopolies, there is increased antitrust scrutiny, thereby creating opportunities for governments to employ competition policy as a non-tariff barrier. Second, since MNEs retain national identities and 'first-movers' appropriate significant profits, governments have incentives to influence nonmarket environments in favour of their home-based MNEs. Third, many citizen groups that oppose MNEs have acquired a broad array of cross-border competencies (not merely country-specific). Their collective opposition is significantly aided by the Internet and by their abilities to manage the media. Fourth, since media is now significantly globalized, local nonmarket issues quickly acquire supranational dimensions. Thus, to respond to these changes, MNEs can be expected to simultaneously develop multi-domestic and supranational (regional and global) nonmarket strategies.
\end{abstract}

\section{KEYWORDS}

Business strategy; nonmarket environment; multinational corporations; NGOs.

\section{ISSUE}

Economic exchanges mediated though market mechanisms require clearly laid out rules that are enforced at low costs. Embedded in social, political, economic and legal institutions, such rules are established, monitored, enforced and interpreted in the nonmarket arena. By impacting both the market and nonmarket environments, globalization is often viewed as empowering multinational enterprises (MNEs) at the expense 
of other societal actors. While MNEs' clout has certainly increased, so have their nonmarket vulnerabilities, particularly vis-à-vis citizen groups. Drawing on international business and international political economy literatures, this paper seeks to advance the understanding about how globalization impacts MNEs' nonmarket environments, thereby both empowering and enfeebling them, and how MNEs can be expected to respond to these changes.

\section{BACKGROUND}

The 'failure' of the World Trade Organization (WTO) meeting (29 November - 3 December, 1999) in Seattle raised important questions regarding the impact of globalization on MNEs' nonmarket environments. With trade ministers from 135 countries at the negotiating table, the Seattle meeting sought to lay out the framework for the ninth round of multilateral trade negotiations (in short, WTO negotiations). ${ }^{2}$ The Seattle meeting 'failed' because the negotiating countries were unable to reach a consensus on the agenda for the ninth WTO round.

Under pressure from labour, environmental and human groups (henceforth citizen groups), ${ }^{3}$ (former) President Clinton made a plea for including labour and environmental standards in WTO negotiations, and he even suggested sanctions (which he subsequently retracted) against countries that do not meet such standards (Raghavan, 2000). Not surprisingly, Clinton's proposal was opposed by developing countries that enjoy a comparative advantage in the export of labour-intensive goods. Free traders saw Clinton's proposal as protectionist. Countries also differed on other issues such as agricultural subsidies (the US and the Cairns group versus the EU) and anti-dumping laws (the US versus the rest of the world). Thus, an important message of Seattle is that notwithstanding globalization, governments continue to champion domestic interests, many times under the guise of new 'international' standards.

The Seattle meeting failed on another count as well. Street demonstrations outside the meeting's venue by labour unions (AFL-CIO, Teamsters, and United Steelworkers of America), environmental groups (Sierra Club, Friends of the Earth and National Wildlife Federation), and other groups (Public Citizen, Consumer Federation of America, Washington Forum of Churches and International Forum on Globalization) indicated the growing backlash against globalization. These groups believe that because globalization favours mobile capital over (relatively) nonmobile resources, it empowers few but impoverishes many, both in developing and developed countries. They allege that capital mobility, both portfolio and foreign direct investment, abet races-to-the-bottom, forcing governments to lower labour and environmental standards. Unrestricted capital flows increase the frequency and severity of financial 
crises (such as in East Asia in 1997) that impose significant hardships on citizens. ${ }^{4}$ Further, they believe that, notwithstanding the 'accountability deficits' and 'democratic deficits,' supranational organizations are laying out a nonmarket architecture of globalization that favours MNEs (Prakash, 2001). Hence, the incentives for citizen groups to oppose such organizations.

In particular, the subject of environmental standards has enraged many groups (Conca, 2000). The WTO judgments on the sea turtles case (against the US' ban on imports of shrimp), the beef hormone case (against the EU's policy to prohibit imports of hormone-treated beef and to allow the US to impose penalties equivalent to the damage suffered by its firms), and the gasoline case (in favour of Venezuelan refiners regarding their exports of gasoline to the US which were banned under the 1990 amendments to the Clean Air Act) are identified as examples in this regard. ${ }^{5}$

The Seattle episode was preceded by a similar one (with citizen groups employing similar tactics) at the Multilateral Agreement on Investment (MAI) meeting in April 1997. Organized under the aegis of the Organization for Economic Cooperation and Development (OECD), the key features of the proposed MAI regime were: national treatment for foreign firms, a ban on performance requirements, limits on the expropriation clause (akin to NAFTA's Chapter 11), and rights to private investors to sue national governments (for details see, OECD, 1998; Brewer and Young, 1998). If enacted, this regime would have strengthened MNEs' bargaining power vis-à-vis national governments. Human rights groups were irked by the most favoured nation (MFN) clause because it could prohibit boycotts of countries that violate citizens' rights. As Kobrin (1998: 104) noted: 'if the MAI had been in force, apartheid would still be with us, Nelson Mandela would still be in jail, and it would be impossible to single out future South Africas for sanctions'.

Akin to Seattle, there were inter-country differences as well. France opposed the MAI fearing that it could enable Hollywood to swamp the French entertainment industry. Excluded from the negotiations process since they were not OECD members, developing countries opposed limits on their rights to regulate foreign investment. In February 1997, the MAI draft was leaked to Nader's Public Citizen and was published on the web. This draft was quickly disseminated around the world and a massive backlash followed. MAI negotiators were forced to meet with citizen groups in October 1997. After failing to revive the talks, the OECD announced in December 1998 that the MAI negotiations were indefinitely halted.

In summary, four lessons emerge from studying the changes in the nonmarket environments facing MNEs. First, to manage increasing levels of cross-border flows, new supranational regimes may be established 
and extant ones strengthened. These regimes will constitute the critical nonmarket arenas where the rules for market exchanges are established, monitored, interpreted and enforced. Second, citizen groups will continue to actively oppose MNEs in the market environment (through, for example, consumer boycotts of sports-apparel manufactured in 'sweat shops') and in the nonmarket environment, both in domestic and supranational contexts. Third, citizen groups realize that their impact on MNEs, governments, and supranational organizations would be greater if they establish cross-border networks. Such transnationally networked groups will seek to impact MNEs' domestic as well as supranational nonmarket environments. Fourth, inter-country differences at the WTO (and previously at the MAI) indicate that notwithstanding globalization, national governments continue to champion domestic interests. Thus, along with supranational nonmarket environments, MNEs would need to manage multi-domestic nonmarket environments as well. In effect, MNEs face 'two-level games' (Putnam, 1988) where what they do in one sphere impacts the other one (more of it below).

To examine the above themes, this paper proceeds as follows. The first section examines why some groups oppose globalization. The second discusses the notion of the nonmarket environment, and how globalization impacts MNEs' nonmarket environment. Conclusions are presented in the last section.

\section{CONCEPTUALIZING GLOBALIZATION}

Globalization is a multi faceted phenomenon having economic, political, cultural, and social dimensions (Appadurai, 1996; Babe, 1996). Economic globalization (henceforth globalization) could be conceptualized as the set of processes that are leading to increased integration of factor, intermediate and final product markets, coupled with the increasing salience of MNEs' value-chains in cross-border economic flows (Prakash and Hart, 2000). Cross-boundary economic integration is not a new phenomenon. Complex webs of economic linkages have existed among ancient civilizations (Wallerstein, 1979). If globalization were to be measured in terms of trade and capital flows, the world economy was perhaps more integrated on the eve of World War I than it is today (Rodrik, 1997). However, the breadth and the depth of the current phase of economic integration is significantly greater (Bairoch and Kozul-Wright, 1998). Further, unlike previous phases of integration, MNEs have a very high salience in cross-border flows. ${ }^{6}$

Previously, I pointed out that countries disagreed in Seattle over the agenda for the ninth WTO quasi-round, thereby refocusing scholarly attention on issues such as the relationship between governments and MNEs, how globalized are MNEs, and who is 'us' and who is 'them' 
(Reich, 1992)? There is a theoretical and empirical literature that examines the levels of MNEs' transnationality (Kobrin, 1991; Sullivan, 1994; Makhija, Kim, and, Williamson, 1997; UNCTAD, 1998). Pauly and Reich (1997) argue that MNEs locate the critical functions - R\&D, systems of innovation and corporate finance - in the parent country.

Therefore, it seems that MNEs still remain rooted in their home economies. Not surprisingly then, governments have incentives, obligations and perhaps even abilities to defend and to promote domestic firms and home-based MNEs (for an opposite view, see Ohmae, 1991). Thus, the evolution of new supranational regimes and transnationalization of citizen groups coexists with the continuing salience of governments as defenders of domestic MNEs. As argued subsequently, this creates incentives for MNEs to play two-level games for simultaneously managing their domestic and supranational nonmarket environments.

\section{Opposition to globalization}

Although foreign trade and investment may increase aggregate welfare, they asymmetrically impact countries (Prebisch, 1959; Hymer, 1976), factors of production (Rogowski, 1989), sectors (Midford, 1993), and firms (Milner, 1988). Consequently, economic integration is perceived to create 'winners' and 'losers'. Often the gains from integration are diffused and in the long term, while the losses are concentrated and in the short term. Losers have incentives to collectively oppose globalization and the presence of organized groups could mitigate collective action dilemmas (Olson, 1965). ${ }^{7}$

Notwithstanding the economic boom of the 1990s, 52 percent of Americans (64 percent with incomes below $\$ 50,000$ ) believed that a global economy hurts Americans (Kohut, 1999). A Gallup poll conducted on the eve of the Seattle meeting reconfirmed that 59 percent of Americans believe that 'increased trade between the United States and other countries' will mostly hurt U.S. workers (Newport, 1999). ${ }^{8}$ Similar trends against economic integration can be observed in Austria and Switzerland, both with low unemployment rates. What explains this opposition? One reason is that globalization is accelerating 'creative destruction'. The fast pace of restructuring is causing economic dislocation: 1.95 million workers were laid off in 1998 and another 1.77 million in 1999 (Bureau of Labor Statistics, 2000). Although the laid-off people often get new jobs easily, arguably the very act of being laid off causes uncertainty that people find difficult to internalize. Thus, opposition to globalization is not rooted in imaginary causes. ${ }^{9}$

Between 1950 and 1998, international trade grew 17 times. Why did people not protest then? This was, in part, due to the 'embedded liberalism' (Ruggie, 1982) compromise, namely that a liberal international 
trade order was embedded in a domestic interventionist state. By expanding and strengthening social safety nets that were first established in mid-nineteenth century, governments sought to compensate losers from free trade. Financed by taxes, such policies constituted collective insurance, thereby preventing free-riding by firms. However, welfare policies have come under attack since the 1980s due to the fiscal crises as well as the changed ideological climate that calls for scaling back the state. ${ }^{10}$ With declining union membership, displaced labour is less powerful in relation to mobile capital. Thus, labour has incentives to play the political card in firms' nonmarket environment by opposing visible targets, such as the WTO, that provide an architecture for globalization.

Importantly, labour unions in developing countries also oppose globalization. This may seem counter intuitive because the relocation of labour-intensive manufacturing industries from developed countries to low-wage developing countries should pit labour unions in these countries against each other. Further, most manufacturing labour in developing countries is unionized - thus, the influx of new jobs potentially expands unions' membership. Then why do unions in developing countries oppose MNEs' entry? One reason is that MNEs' entry increases the levels of competition in typically over-staffed industries that have traditionally been protected from domestic and foreign competition. Thus, unions believe that jobs will be lost to less labour-intensive MNEs.

As debated in last year's US Presidential election, although globalization is creating economic prosperity, inequality is increasing. In the US, the ratio of top executive to factory worker pay has dramatically increased over the last two decades: from 42 in 1980 to 419 to 1998 (Washington Post, 1999). The richest 1 percent of Americans (2.7 million individuals) account for 12.9 percent of all income (7.3 percent in 1977) and receive after-tax income comparable to the bottom 100 million (49 million in 1997) (New York Times, 1999). The levels of inequality will be greater if measured in terms of assets (real and financial), given the skewed nature of asset ownership in the US. These trends reinforce the perception that globalization is benefiting only a small section of society. Thus, opposition to globalization is not transient - it is rooted in material factors (labour interests) as well as in non- material factors (environmental and human rights issues). Eventually, both these factors are about 'rights', perhaps the 'old' rights (material interests) as well as the 'new' rights (nonmaterial interests). ${ }^{11}$

Arguably, citizen groups fear that globalization processes provide cover for MNEs to work towards establishing new supranational regimes or strengthening extant ones which are beset with 'accountability deficits' and 'democratic deficits'. The distrust is compounded because governmental delegations at these inter-governmental fora often seem to represent business interests. Further, some supranational organizations work 
in secrecy, not offering opportunities for public input. The WTOs dispute resolution proceedings are held in-camera, thereby denying access to citizen groups to participate or even to file briefs. In contrast, the US Administrative Procedure Act requires federal agencies to seek public input on new regulations. ${ }^{12}$

However, blanket claims about MNEs (citizen groups) favouring (opposing) supranational regimes require careful examination (Levy and Prakash, 2001). Based on two attributes, regime purpose (regulation versus market creation) and the location of monitoring and enforcement authority (domestic versus supranational levels), four broad types of supranational regimes can be identified: international market facilitating; domestic market facilitating; domestic regulatory; and international regulatory. Most citizen groups can be expected to support (and MNEs expected to oppose) establishing regulatory regimes which tend to reduce corporate autonomy. However, some MNEs may support specific regulations due to strategic, political and competitive considerations. The domestic political economy literature suggests that firms that are able to 'capture' (Stigler, 1971) the regulators have often supported new laws and regulations (Bernstein, 1955; Kolko, 1963). Further, MNEs that can shape new regulations because of their technological competencies (Fri, 1992; Reinhardt, 1999) and reap first-mover advantages (Porter and van der Linde, 1995; Nehrt, 1998; for a critique see, Rugman and Verbeke, 1998), may favour new regulatory regimes. It seems, therefore, that MNEs may not oppose regulatory regimes per se; but only specific kinds that put them at competitive disadvantage. Conceivably, citizen groups and some MNEs could form a 'Baptist-Bootlegger' (Vogel, 1995) alliances in support of such regulatory regimes. Claims about citizen groups' and MNEs' preferences for locating enforcement and monitoring mechanisms at domestic versus supranational levels also require examination. At a broad level, actors' preferences for locating authority in a given arena is influenced by the degree of power in and access they enjoy in this arena. MNEs are frequently portrayed as favouring supranational arenas because nationally organized groups such as unions and environmentalists are more powerful in domestic politics. MNEs may not to want be regulated by domestic regulators with whom they have had a history of adversarial relations (Kollman and Prakash, 2001) However, given their domestic-rootedness, MNEs could be in a better position to influence domestic regulators rather then international ones. In addition, for regulatory regimes requiring significant scientific input, MNEs may not have requisite influence over international 'epistemic communities' (Haas, 1990).

The issue of access to regulatory institutions also influences actors' preferences about them. Marks and McAdam (1996) argue that labour and anti-nuclear groups have been less inclined to support the strengthening 
of the European Union (EU) because of less formal access they have to the EU structure and the constraints they face in establishing a pan European identity. On the other hand, environmental groups have welcomed European integration partially because the EU structures provided them with ample institutional access and their abilities to forge a pan European identity. Thus, environmental groups perceive themselves to enjoy a greater clout with the transfer of authority to a supranational level. Clearly, citizen groups and/or MNEs may exhibit varying preferences for various regulatory arenas. ${ }^{13}$

In sum, the opposition to globalization is being articulated both at the domestic and supranational levels. Arguably, the Seattle episode suggests that politics is local because governments continue to champion domestic interests. While this may be true, Seattle (and the MAI) also signify the growing importance of supranational regimes in shaping cross-border flows, thereby creating incentives for citizen groups to network in order to influence them. Preferences of MNEs/citizen groups for national versus supranational, and regulatory versus market enabling regimes depend on multiple factors such as power and access they enjoy in different institutional arenas. As argued subsequently, this will create incentives for MNEs to develop and to integrate multi-domestic and supranational nonmarket strategies.

\section{IMPACT OF GLOBALIZATION ON MNES' NONMARKET ENVIRONMENT}

Market-based economies function effectively if property rights are clearly delineated, monitored and enforced at low costs (North, 1990). Typically, governments (executive, legislature and judiciary) are the main agencies that perform these functions. At a broader level, because governments set most (not all) rules within which market actors function and private contracts are negotiated (Lindblom, 1977), firms have incentives to influence policy processes (Stigler, 1971; Buchanan et al., 1980; Marcus et al., 1987; Mitnick, 1993; Shaffer, 1995). Firms' access to nonmarket actors, processes, and institutions varies within and across countries. The literature on MNE-government relationships (governments being the most important nonmarket actors) is vast, focusing on how governmental policies impact MNEs' strategies, processes and performance and vice versa (Vernon, 1971; Gilpin, 1975; Porter, 1990; Eden, 1991; Lenway and Murtha, 1994; Caves, 1996; Grosse, 1996; Rugman and Verbeke, 1998a; Kostova and Zaheer, 1999; Hoskisson et al., 2000). Scholars have also examined how institutions, both domestic and supranational, impact MNEs' structures (such as locating their government relations department) and strategies (lobbying, contributing to political action committees, working individually or through industry-level associations) 
(Preston and Windsor, 1992; Murtha and Lenway, 1994; Hillman and Keim, 1995). There is also a body of research on how MNEs influence supranational inter-governmental and private institutions (Braithwaite and Drahos, 2000; Cutler et al., 1998) and how, and to what extent, citizen groups influence international trade and environmental policy debates (Wapner, 1995; D. Vogel, 1995; Clark et al., 1998). This paper does not survey these literatures. Instead, it examines how globalization is impacting MNEs' nonmarket environments and how MNEs can be expected to respond to these changes. For this, I begin by drawing upon the work of David Baron.

Baron (1995a, 1995b, 2000) emphasizes the role of nonmarket environments in influencing market outcomes. Nonmarket environments consist of the 'social, political, and legal arrangements that structure the firms' interactions outside of, and in conjunction with, markets' (Baron, 1995a: 48). ${ }^{14}$ They differ from market environments in terms of decision-making processes (majority rule, due process and broad enfranchisement in nonmarket environments), firms' control over the processes (market processes are voluntary, nonmarket ones may be involuntary as well), who participates in these processes (stakeholders having economic and non-economic interests in nonmarket environments), and levels of the 'free rider' problem (high in nonmarket environments). Since strategies to deal with nonmarket and market environments differ, Baron emphasizes that firms should integrate their market and nonmarket strategies.

Bartlett and Ghoshal (1989) identify three mentalities/strategies (global, international, multi-domestic) that MNEs adopt to deal with the opposing pressures of globalization (tapping economies of scale) and localization (tailoring strategies to serve country-specific needs). Global strategies are predicated on an integrated world market and require firms to adopt a given strategy across countries. If political boundaries significantly impact the nature of markets, then global strategies are less useful. International strategies require transferring parents' expertise to foreign markets while multi-domestic strategies are developed to respond to country-specific needs. ${ }^{15}$

Baron suggests that nonmarket strategies should be examined in the context of institutions, actors and issues. Since these often vary across countries, he calls for MNEs to adopt multi-domestic strategies, as opposed to global or international ones:

A comprehensive global or international nonmarket strategy seems unlikely to be successful, however, because strategies must take into account the institutions in whose context nonmarket issues are addressed, the configuration of interests in a country, and other country-specific factors. Many nonmarket issues have a strong domestic orientation and are more likely than market strategies to 
require multi-domestic strategies. The successful implementation of a multi-domestic strategy involves issue-specific action plans that are tailored to the configuration of institutions and interests in individual countries.

(1995a: 62-3)

This paper argues that with the accelerating pace of economic globalization, in addition to multi-domestic strategies, MNEs can be expected to adopt supranational strategies. Although globalization processes are causing many interests (especially the ones that oppose MNEs) and institutions (where rules are established, monitored and enforced) to assume a supranational character, the domestic nonmarket environment (particularly, the power of and incentives for governments to influence market processes) remains important. National governments continue to play important roles in shaping the evolution of supranational regimes. And, domestic politics matters in influencing what governments do or do not do. Therefore, the nonmarket challenge facing MNEs would lead them to simultaneously develop multi-domestic policies that fit into their supranational nonmarket strategies as well as to develop supranational strategies (in relation to supranational institutions and actors) that are consistent with their multi-domestic ones. This is a challenging task given an increasing divergence among countries on how globalization processes need to be managed - Seattle and MAI being telling examples. A need for domestic focus in shaping nonmarket strategies and yet ensuring that there is global coherence raises important issues for MNEs in devising their organizational goals, structures, and processes.

\section{Changes in nonmarket environments}

Globalization impacts MNEs' nonmarket environments in the following ways: by creating new incentives for governments to influence economic activity; by creating conditions for the emergence of new supranational regimes or for the strengthening of extant ones; by inducing opposition from transnationally networked citizen groups; by providing new channels of information flows; and by consolidating the media industry whereby local events are quickly transformed into transnational ones.

Governmental interventions and regimes

Globalization is creating incentives for governments to privatize, liberalize and deregulate (Ramamurthi and Vernon, 1991; De Castro and Uhlenbruck, 1997). ${ }^{16}$ How these processes take place - what to privatize, liberalize, deregulate; and how, when, etc. - is decided primarily in nonmarket environments, both domestic and supranational (Feigenbaum et al., 1999). Domestic politics and ideological climate create political space 
for these changes. At the supranational level, international organizations such as the IMF and the World Bank have required borrowing countries to adopt market-friendly policies.

Further, in response to the emergence of new products and new modes of transactions (the Internet), as well as to correct the failures of ill planned and/or badly executed market-facilitating policies, one expects to see a demand for new regulations (California electricity market being a recent example). Although some have argued that such regulatory mechanisms (particularly, the Internet) should remain in the private domain (Spar, 1999), self-governance by market actors may not always be feasible or desirable (Polanyi, 1957). Private governance also may not be selfenforcing and may require the coercive apparatus of public law. The upshot then is that deregulation and reregulation go hand-in-hand (S. Vogel, 1998). And policies regarding what, when, and how to deregulate or to regulate - all decided in nonmarket arenas - have crucial bearing on MNEs' market strategies. ${ }^{17}$

Baron suggests that nonmarket strategies are more important in sectors where opportunities are influenced by governments. In the 1990s, surges in cross-border mergers and acquisitions (M\&A) - an integral component of globalization - have created oligopolies in many industries. ${ }^{18}$ For perspective, M\&As increased from $\$ 49$ billion in 1991 to $\$ 163$ billion in 1996, and to $\$ 411$ billion in 1998 (UNCTAD, 1999). Major industries (such as automobiles, petroleum exploration, semiconductors, consumer electronics, insurance, banking) now have eight to ten key players that account for 70-80 percent of the global output (Zachary, 1999). Not surprisingly then, there is an increased level of antitrust scrutiny, especially in the US and the EU - the scrutiny of the BoeingMcDonnell Douglas merger, British Airways-American Airlines alliance, MCIWorldCom-Sprint merger, and recently, GE-Honeywell merger being notable examples of regulators restraining the emergence of (potential or actual) cross-border oligopolies. The number of transactions reported to the Federal Trade Commission and the Justice Department under the Hart-Scott-Rodino Act has tripled in the 1990s: from 1529 to 4642 in fiscal 1999 (Parker, 2000). Lest antitrust actions become nontariff barriers or cartel-sponsored private barriers become obstacles to trade and investment flows, key issues are whether, when, and how to establish an international regime (or modify an extant one) on competition policy..$^{19}$ Needless to say, this has an immense bearing on MNEs' nonmarket environments.

Globalization also creates incentives for governments to intervene in favour of domestic MNEs in terms of 'macroeconomic' and 'macrostructural' policies (Dunning, 1993). In the 1980s, strategic trade theorists (STT) argued that in industries marked by imperfect competition, high positive externalities and supernormal profits (characteristics of the new 
oligopolies as well), firms are often locked in a zero-sum game, and governments have incentives to intervene in favour of domestic firms (Dixit, 1983; Brander and Spencer, 1985; Krugman, 1994b). Boundaries between domestic and international are blurred because domestic interventions (such as tariff and non-tariff protection, R\&D subsidies) can tilt the scale in favour of domestic firms in global markets. Arguably, given the fast pace of product obsolescence, a winner-takes-all situation is developing in many industries. Consequently, MNEs have incentives to emerge as winners, if not through market processes then through nonmarket strategies. ${ }^{20}$ Thus, globalization processes create incentives for MNEs to enlist support from their home governments and create an obligation for governments to support them (Stopford and Strange, 1991; for a critique see, Reich, 1992; Rugman and Verbeke, 1998a). ${ }^{21}$

\section{Citizen groups and the media}

Although domestic governments may be willing to support MNEs, a major threat has emerged from transnationally networked citizen groups, many of which believe that MNEs are their common 'enemy'. The Yearbook of International Organizations estimates the number of international NGOs (operating in more than one country) in 1999 at 26,000 up from 6,000 in 1990 and 3,000 in 1960 (The Economist, 1999: 19). These group may operate within the traditional state-centric system by influencing governments, or independent of it by directly influencing MNEs (Vogel, 1978), consumers and policy discourses (Wapner, 1995). In recent years the latter perspective has gained currency with many scholars suggesting that global civil society and global politics - organized social life and politics that are autonomous of the state and outside the state-centric system - has emerged (Rosenau, 1990; Lipschutz, 1992; Diamond, 1994; Wapner, 1995, for an opposing view, see Clark et al., 1998).

Berry (1999) suggests that citizen lobbies now focus predominantly on postmaterial issues (consumer issues, environmentalism and minority rights) rather than economic issues (import duties, manpower training, farm price support). This also is reflected in the changes in the US Congress's agenda over last four decades: in the 1960s about two-thirds of the proposals were economic while by 1991 about 70 percent were postmaterial. Arguably, given their nonmaterial incentives (labour groups being the exception), citizen groups perhaps face fewer Olsonian collective action problems in opposing MNEs.

Realizing that their strength lies in numbers, citizen groups have incentives to co-ordinate their strategies across borders. The Internet has reduced the costs of organizing collective action - the mobilization against the MAI meeting (Kobrin, 1998) and the Seattle meeting being notable examples. ${ }^{22}$ Many citizen groups are quite media savvy, often managing 
to outmanoeuvre their corporate opponents. ${ }^{23} \mathrm{~A}$ telling example is the controversy over the dumping of the Brent Spar buoy (often incorrectly described as an oil platform) in the North Sea in 1995. The main actors were Greenpeace and Royal Dutch/Shell (3rd largest MNE in terms of assets; with 1997 sales of $\$ 128$ billion). Shell used the Brent Spar buoy as storage and tanker loading facility for its Brent oil field in the North Sea. In 1991 the buoy was decommissioned, and after extensive internal scientific evaluation, discussions with British governmental agencies, and consultation with British stakeholders regrading the environmental and safety aspects of various disposal options, Shell decided to dump it in the North Sea rather than to bring it onshore for dismantling. Greenpeace opposed dumping of the buoy in the sea, a position that had considerable support in continental Europe, though not in the UK. Through dramatic actions (such as boarding and occupying the buoy) that were captured on television, excellent media management and grassroots mobilization across countries (including consumer boycotts and the firebombing of Shell stations in Germany), Greenpeace forced Shell to bring the buoy back onshore for disassembly. Subsequently, Greenpeace admitted that its favoured option had worse environmental consequences than Shell's. Nevertheless, in the heat of the controversy, the media gave prominence to Greenpeace over Shell.

An important implication is that because the media industry is now increasing globalized (both in terms of ownership and content), local events such as Brent Spar quickly impact market and nonmarket environments in other parts. Thus, MNEs are losing their abilities to localize damage from adverse media coverage, even if their actions are defensible on scientific and technical grounds. Their response time has also been reduced. These trends suggest that MNEs now require supranational nonmarket strategies on issues that can potentially spill over borders, and most issues seem to be developing this potential.

Because globalization leads to a high degree of cross-border economic linkages, MNEs become vulnerable to political developments in their home and host countries. Citizen groups in home/host countries can impact MNEs' strategies in yet another country. US citizen groups, notably the Natural Resources Defense Council, in alliance with Mexican groups, forced Mitsubishi to shelve a $\$ 100$ million investment in a salt plant on the shores of Laguna San Ignacio where gray whales breed: 'And as Mexico received $\$ 11.6$ billion last year in long-term investments from abroad, it also discovered that it cannot ignore the other forces, like the environmental movement, that are criss-crossing borders and making politics into a global game' (Preston, 2000: 9). The message is clear: if MNEs invest in multiple markets, they need to deal with citizen groups in multiple countries. And this would require MNEs to integrate their supranational and multi-domestic nonmarket strategies. 
A lack of such integration can impose significant costs - Royal Dutch/ Shell's experience in the global warming debate being a notable example. There is wide divergence within and among countries on the existence, causes and consequences of global warming. MNEs with FDI in multiple countries could be faced with tricky situations where only some governments wish to ratify the Kyoto protocol. Thus, relying on multi-domestic nonmarket strategies may make MNEs appear inconsistent. Royal Dutch/Shell faced this predicament recently. Due to the varying domestic political economies, Shell's UK and Dutch parents have consistently supported the Kyoto protocol while Shell USA opposed it. Being a visible member of the anti-treaty US-based Global Climate Change (GCC) coalition, Shell USA criticized the Kyoto protocol in the main text of its 1998 annual report. Shell's inconsistency was quickly seized upon by environmental groups. Sensing a damaging political fallout, the European parent forced its US subsidiary to repudiate its opposition in an addendum of the same report (for details, see Kolk, 2000: 72). This flip-flop took a toll on Royal Dutch/Shell's credibility with environmental groups. To mollify this important actor in its nonmarket environment, Royal Dutch forced its US subsidiary to withdraw from the GCC coalition in April 1998. Thus, relying on multi-domestic nonmarket strategies alone will not work for MNEs because both economics and politics now have important global dimensions.

It some ways globalization also empowers MNEs to better influence their nonmarket environments through their cross-border 'rent chains' (Baron, 1995a). Rents are returns on resources above their opportunity costs. Rents manifest themselves in many forms: supernormal profits for industries protected from imports or high wages for labour whose unions have forced governments to restrict imports from low-wage countries. Because of extensive forward and backward linkages, MNEs often create rent chain networks across jurisdictions. MNEs can be expected to organize these networks for nonmarket action. ${ }^{24}$ Thus, along with the increased supranational reach of citizen groups and the media that potentially disadvantage MNEs in nonmarket arenas, transnational rent chain networks can be expected to serve as useful resources for MNEs' nonmarket activities, particular their global strategies.

To summarize, this section suggests that globalization is changing MNEs' nonmarket environments in four ways. First, it is leading to deregulation as well as reregulation. Because cross-border consolidations are creating global oligopolies industries, there is increased antitrust scrutiny. Instead of a national orientation, competition policy is moving toward a regional and global focus. Second, since MNEs retain national identities and first-movers appropriate significant profits, governments have incentives to influence nonmarket environments in favour of home-based MNEs. Third, many citizen groups that oppose MNEs have acquired a 
broad array of cross-border competencies (not merely country-specific). Exercising both 'structural' and 'relational' power (Strange, 1999), these groups seek to change the existing rules of global commerce and investment and to prevent new ones that empower MNEs over other societal actors. Their collective opposition is significantly aided by the Internet and their abilities to manage the media. Fourth, since the media is now significantly globalized, local nonmarket issues quickly acquire supranational dimensions. Thus, to simultaneously respond to such two-level games, MNEs can be expected to develop multi-domestic and supranational nonmarket strategies (including mobilizing their rent chains) and to ensure that these strategies cohere.

\section{CONCLUSIONS}

Like any other societal actor, MNEs are impacted by globalization in ways they cannot adequately control. As economics begins to have important global dimensions, so does politics. MNEs increasingly confront supranational actors who oppose them, supranational regimes that govern their behaviour, and global media that scrutinize them. At the same time, however, domestic politics of home/host countries remain critical for MNEs' operations. This paper therefore argues that pressures to simultaneously manage domestic and supranational nonmarket issues, actors, and institutions would create incentives for MNEs to play twolevel games (Putnam, 1988; Evans et al., 1994). ${ }^{25}$

In response to an important International Relations' debate on how best to explain countries' foreign policies (in terms of domestic imperatives, the 'second-image'; or international structures, the 'third-image'), Putnam argued that domestic and international imperatives need to be considered simultaneously:

The politics of many international negotiations can usefully be conceived as a two-level game. At the national level, domestic groups pursue their interests by pressuring the governments to adopt favorable policies, and politicians seek power by constructing coalitions among those groups. At the international level, national governments seek to maximize their own ability to satisfy domestic pressures, while minimizing the adverse consequences of foreign developments.

(Putnam, 1988: 434)

Read the above quote by substituting MNEs for national governments. ${ }^{26}$ The salience of domestic and supranational arenas for MNEs would differ across issue areas, depending on, inter alia, the actors that are engaging MNEs, the institutional context, and the trans-border appeal of the issue. The impact of home/host countries on MNEs' strategies 
would also vary because developing countries typically have much less bargaining power vis-à-vis MNEs. Thus, in playing a two-level game, MNEs may get conflicting pressures from both levels: crafting multidomestic strategies could sacrifice their global applicability but supranational strategies may not fill perfectly well in every domestic context.

This paper suggests that citizen groups have emerged as key actors that MNEs need to take into account. MNEs' strategies to confront, co-opt, and/or collaborate with these groups can be expected to be nuanced because significant differences exist within citizen groups regarding their aims, capabilities, and orientations. For example, literature points out that citizen groups from the North and South differ in fundamental ways (Hollway, 1998; Abramson, 1999; Malhotra, 2000). This would clearly pose a challenge for MNEs operating in both developed and developing countries because working with one set of stakeholders may offend some others. In this regard, the criteria of power, legitimacy, and urgency that Mitchell et al. (1997) offer to managers in classifying stakeholders merits attention. Because giving equal salience to all stakeholders is difficult, managers are advised to identify which stakeholders have the power and legitimacy and which managerial responses require urgency. Based on these attributes, managers could decide which stakeholders' concerns will be addressed, when, and how. Such decisions will be challenging if different stakeholders in the domestic and supranational arenas are powerful and/or legitimate and different sets of managerial actions are deemed urgent by them. Further, as discussed above, stakeholders from the South may be disadvantaged if managers were to adopt the decision criteria suggested by these authors.

To conclude, globalization is impacting various societal actors in multiple ways. While MNEs' clout has increased in some areas, so have their vulnerabilities. A key challenge for scholars of international political economy is to examine how globalization is impacting various actors and social relationships, and how these actors have (could) responded (respond) to these changes. This paper has contributed to this endeavour by examining how globalization impacts the nonmarket environment, and how MNEs can be expected to respond to these changes.

\section{NOTES}

1 This is a revised version of a paper presented at the 41st annual meeting of the International Studies Association, Chicago, February 20-24, 2001. I thank Jonathan Doh, Virginia Haufler, Dan Kane, David Levy, Jean Boddewyn, and the anonymous reviewers for comments on the previous drafts, and Amit Prasad for his research assistance.

2 The previous eight rounds were held under the auspices of the General Agreement on Tariffs and Trade (GATT), the WTO's predecessor. Hence, technically, the Seattle meeting did not constitute the ninth WTO round. 
3 I employ the term citizen group (instead of non-governmental organizations, civil society organizations, the third sector, or the independent sector) to refer to non-business and non-governmental groups that seek to influence firms' market and nonmarket environments. Drawing upon the East European and Soviet experiences, scholars have employed the term civil society to describe those 'aspects of social and cultural life that had not been captured or colonized by the totalitarian state' (Lipschutz, 1992: 391-2). My focus is on groups that have been colonized neither by the state nor by businesses. However, it needs to be pointed out, in many countries citizen groups rely on governmental financing. This accounts for between 47-78 percent of their incomes in Ireland, Germany, Israel, The Netherlands, and the UK. On an average, private philanthropy provides only 11 percent of their revenues (Then and Walkenhorst, 1999). Thus, the levels of autonomy from governments that citizen groups are perceived to enjoy may not be as significant as it is made out to be.

4 Financial globalization makes countries vulnerable to exogenous shocks. To prevent destabilizing capital outflows, governments are forced to raise interest rates (thereby, causing economic downturns) and to shrink budgets, often undermining their abilities to deliver healthcare, education, and social-safety nets. Obviously, these forced policies undermine countries' short and longterm economic development. Based on a study of 86 developed and emerging economies, the IMF concluded that on average, financial crises take about three years to overcome and cause an economic loss of over 10 percent of GDP (IMF, 1998).

5 This is over and above previous cases including the Tuna-Dolphin case that held the U.S. Marine Mammals Protection Act of 1972 to be inconsistent with the GATT. The WTO rulings are not alone in stoking the anger of citizen groups. Under Chapter 11, Article 1103 of the North American Free Trade Agreement (NAFTA), each party is expected to accord national treatment to the investors from other signatories. Claiming expropriation, US-based MMT manufacturer, Ethyl Corporation, sued the Canadian Government for \$250 million in damages due to Canada's ban (emanating from Bill C-29 passed in 1997) on MMT imports. The Canadian government capitulated and settled the suit for $\$ 13$ million. Citizen groups viewed this as yet another instance where supranational trade agreements have undermined governments' abilities to protect the environment and the health of their citizens. The MMT case, unfortunately, not been adequately understood, and perhaps even misrepresented. Bill C-29 prohibited imports and interprovincial trade in MMT. It did not prohibit Canadian firms from manufacturing MMT. Thus, the Canadian government was in weak legal standing as Bill-29 discriminated against foreign manufacturers, thereby violating NAFTA's 'national treatment' clause (Hufbauer et al., 2000). Arguably, had the Canadian government prohibited $\mathrm{MMT}^{\prime \prime}$ s domestic production as well, the final outcome would have been different.

6 Multiple indicators reflect the MNEs' key economic role in the contemporary world economy (UNCTAD, 2000): inward FDI stock has surged from $\$ 1$ trillion in 1987 to $\$ 4.8$ trillion in 1999, and MNEs' value chains account for about 10 percent of world GDP (5 percent in the mid-1980s). Data suggest that the so-called Triad accounts for 60 percent of FDI inflows. Rugman and D'Cruz (2000) point out that most manufacturing sectors are regionally, not globally integrated. It remains to be seen whether regional integration will be a 'building block' or a 'stumbling block' to global integration (Lawrence, 


\section{REVIEW OF INTERNATIONAL POLITICAL ECONOMY}

1995). Though not examined in the paper, if regional integration leads to the establishment of regional level regulatory institutions, MNEs may then have incentives to develop regional nonmarket strategies in addition to domestic and global ones.

7 This is not to suggest that the resistance to globalization/neoliberal policies began only in the 1990s. In the 1980s, citizen groups in developing countries actively opposed IMF's structural adjustment policies. I owe this point to the anonymous reviewer.

8 Krugman (1994a) argues, however, that international trade accounted for only 20 percent reduction in the earnings of low-skilled American workers. The main culprits were a slow growth in domestic productivity and slower increases in demand for unskilled labour relative to that of skilled labour.

9 As Dunning observes (2000: 476):

There appeared to be little appreciation that unlike trade liberalization (essentially a question of reducing cross-border market imperfections), any movement towards the harmonization of environmental or labor standards, of immigration laws, of competition policies, or of action towards bribery and corruption - need not necessarily result in a 'winwin' situation for all parties.

10 For a forceful argument why globalization is not sapping the fiscal capacities of governments, see Kudrle (2000).On the continued resilience of the 'welfare state', see Pierson (1996).

11 I thank David Levy for this point.

12 Citizen groups have also come under criticism. Mathews (1997: 64) notes:

For all their strengths, NGOs are special interests, albeit not motivated by personal profits. The best of them, the ablest and the most passionate, often suffer most from tunnel vision ... A society in which the piling up of special interests replaces a single strong voice for the common good is unlikely to fare well. Single-issue voters, as Americans know all too well, polarize and freeze public debates.

13 Citizen groups may also not speak in one voice due to their clashing interests, economic or non-economic: the AFL-CIO opposes the ratification of the Kyoto treaty but most environmental groups support it.

14 For a thoughtful critique of the notion of nonmarket environment and exchange, see Boddewyn (1999).

15 Hout et al. (1982) suggest that global strategies are useful when a firm's competitive position in one market is impacted by its position in other markets. The literature on the concept and appropriateness of global strategies is vast. Some key works include Hamel and Prahalad (1985), Kogut (1985), and Prahalad and Doz (1987).

16 As argued elsewhere, privatization, liberalization and deregulation may serve both as the causes and the consequences of globalization (Prakash and Hart, 1999).

17 A vast majority of FDI reregulations favour MNEs: between 1991-9, 94 percent of 1035 changes in FDI laws favored MNEs (UNCTAD, 2000: xv). At the same time, there are trends towards reregulating key industries to rein in firms. Consider two examples. The US airline industry was deregulated in the 1978 by the Carter Administration. In the last few years, in response to poor service and industry consolidation, there is a demand for reregulation. Not surprisingly, 26 bills have been introduced in the 107th US 
Congress that seek to preserve competition and to establish passenger rights. Second example pertains to the US biotech industry which has not faced many new regulations since the mid 1980s.However, due to recent developments including the StarLink episode, a number of bills were introduced in the 106th US Congress to regulate this industry: These are: H.R. 3266 (Brown), H.R. 3377 (Kucinich), H.R. 3883 (Holt), H.R. 5095 (Tierney), H.R. 5591 (Kucinnich), S.18 (Harkin)/H.R. 983 (Baldacci), S. 908 (Dorgan)/ H.R.1612(Pallone), S. 1126 (Mikulski)/H.R. 2055 (Pallone), S.1281 (Dubin)/ H.R. 2345 (DeLauro), S.1868 (Durbin)/H.R.3526 (Pallone), S. 2080 (Boxer), S.2106 (Ashcroft), S.2315 (Moynihan), S. 2480 (Collins), S.2692 (Mikulski), S.2760 (Harkin), S. 2838 (Hutchinson), and S. 3184 (Durbin) (for details, see Vogt, 2000).

18 The EU can investigate the merger of entities (and impose sanctions on them) whose combined sales exceed $\$ 4.5$ million in the EU area, irrespective of where these entities are headquartered. Many industries, therefore, correspond to Yoffie's (1994) 'regulated competition' model. This is not to say that cross-border M\&As always create oligopolies. In many cases, they may create contested markets. However, how such M\&As impact levels of competition depends on competition policy, an area in which governments exercise sizeable influence.

19 The WTO does cover some issues pertaining to competition policy. Recently, it upheld the EU's complaint regarding a $\$ 1.4$ billion tax break (an export subsidy) provided by the US government to its exporters under the Foreign Sales Corporation (FSC) law. FSC allows US companies to set up offshore subsidiaries that are partially exempted from US corporate taxes. US companies channelled some of their export profits through these subsidiaries and the WTO found this to be in violation with WTO rules.

20 Examples are numerous. Airbus invoked political help to ensure that the EU required Boeing to shed its exclusive supply contracts with three major American airlines in return for its approval for the merger with McDonnell Douglas. President Chirac was quite vociferous in this regard. The EU objections to MCIWorldCom-Sprint merger are attributed (partially) to lobbying by French and German governments who fear that France Telecom and Deutsche Telecom will be locked out of the internet-backbone market.

21 Of course, competing domestic industries often want different policy outputs from governments. The point I am trying to make is that claims about the demise of the state, that firms no longer have national identities, and that governments are becoming less powerful to influence market outcomes, are exaggerated if not invalid.

22 Internet users worldwide increased from 0.7 million in 1991 to 407 million in November 2000 (Nua, 2000). Half of the US public has access to the Internet, as opposed to about one fourth in 1997 (Kohut, 2000). Data also suggest that, for many, the Internet has emerged as a key source for information on current affairs and politics.

23 The media is also giving more coverage to citizen groups: in both network TV news and the printed press. For details see, Berry (1999). The media industry is getting more concentrated, and arguably, it is not a disinterested player in the various globalization debates. Further, as media companies come to rely more on advertisement revenues (rather than user fees or governmental budgetary support), they become vulnerable to pressures from their advertisers (rather than politicians and bureaucrats). To increase their viewership/readership, these companies are also under pressure to be the 


\section{REVIEW OF INTERNATIONAL POLITICAL ECONOMY}

first to report news (thereby perhaps upsetting their advertisers). My numerous in-depth discussions with business executives suggest that firms are indeed very concerned about getting bad media and often feel powerless to influence the content, mode, and timing of media coverage regarding their policies and actions. In an ongoing research that examines the controversy over the use of poly-vinyl chlorides (PVC), I examine how Greenpeace outmanoeuvred Baxter International by employing media to embarrass and to incorrectly report Baxter's position on this subject. Inspite of considerable resources and experience with media, Baxter was unable to offset the 'damage' inflicted by Greenpeace.

24 Clinton Administration's decision to levy punitive import tariff on Japanese luxury cars led Japanese auto companies to mobilize their dealer networks in the US against this policy, including for demonstration at the Capitol Hill.

25 The anonymous reviewer correctly points out that the two-level game approach would be equally helpful for citizen groups in developing their strategies to oppose MNEs.

26 Arguably, there are multiple levels where nonmarket strategies need to be co-ordinated: subnational, national, regional, and international. For keeping my argument simple, I focus only at the domestic and supranational levels.

\section{REFERENCES}

Abramson, D.M. (1999) 'A critical look at NGOs and civil society as means to an end in Uzbekistan', Human Organization 58: 240-250.

Appadurai, A. (1996) Modernity at Large: Cultural Dimensions of Globalization. Minneapolis, MN: University of Minnesota Press.

Babe, R.E (1996) Communication and the Transformation of Economics: Essays in Information, Public Policy, and Political Economy. Boulder, CO: Westview Press.

Bairoch, P. and Kozul-Wright, R. (1998) 'Globalization myths: Some reflections on integration, industrialization and growth in the world economy', in R. Kozul-Wright and R. Rowthorn (eds), Transnational Corporations and the Global Economy. New York: St. Martin's Press.

Baron, D. P. (1995a) 'Integrated strategy: Market and nonmarket components', California Management Review 37: 47-65.

Baron, D.P. (1995b) 'The nonmarket strategy system', Sloan Management Review, Fall: 73-85.

Baron, D.P. (2000) Business and Public Policy, Third edition. Upper Saddle River, NJ: Prentice Hall.

Bartlett, C.A. and Ghoshal, S. (1989) Managing Across Borders. Boston, MA: Harvard Business School Press.

Bartlett, C.A. and Ghoshal, S. (1992) 'What is a global manager?', Harvard Business Review 70.

Berry, J. (1999) The New Liberalism: The Rising Power of Citizen Groups. Washington, DC: The Brookings Institution.

Boddewyn, J. (1988) 'Political aspects of MNE theory', Journal of International Business Studies, 19: 341-136.

Boddewyn, J. and Brewer, T.L. (1994) 'International business political behavior', Academy of Management Review 19: 119-143.

Boddewyn, J.J. (1999) "NonMarket" environment and exchange: A concept whose time has gone?', Working Paper, New York: Baruch College.

Braithwaite, J. and Drahos, P. (2000) Global Business Regulation. Cambridge University Press. 
Brewer, T.L. (ed.) (1985) Political Risk in International Business. New York: Praeger Publishers.

Brewer, T.L. (1992) 'An issue area approach to the analysis of MNE-government relations', Journal of International Business Studies 23: 295-310.

Brewer, T.L. and Young, S. (1998) Multinational Investment Rules and Multinational Enterprises. New York: Oxford University Press.

Brander, J.A. and Spencer, B.J. (1985) 'Export subsidies and international market share rivalry', Journal of International Economics 18: 85-100.

Buchanan, J., Tollison, R. and Tullock, G. (eds) (1980) Towards a Theory of the Rent-Seeking Society. College Station, TX: Texas A\&M Press.

Bureau of Labor Statistics/BLS (2000) Labor force statistics from the current population survey, <http://146.142.4.24/cgi-bin/surveymost; 4/7/2000>.

Caves, R.E. (1996) Multinational Enterprises and Economic Analysis, 2nd edition. Cambridge: Cambridge University Press.

Clark, A.M., Friedman, E.J. and Hochstetler, K. (1998) 'The sovereign limits of global civil society', World Politics 51: 1-35.

Conca, K. (2000) 'The WTO and the Undermining of Global Environmental Governance', Review of International Political Economy 8: 484-494.

Cutler, A. Claire, Haufler, V. and Porter, T. (eds) (1999) Private Authority and International Affairs. Albany, NY: SUNY Press.

De Castro, J. O. and Uhlenbruck, L. (1997) 'Characteristics of privatization: Evidence from developed, less-developed, and former communist countries', Journal of International Business Studies 28: 123-143.

Diamond, L. (1994) 'Towards democratic consolidation', Journal of Democracy 5: 4-17.

Dixit, A. (1983) 'International trade policy for oligopolistic industries', Economic Journal 94: 1-16.

Dunning, J.H. (1993) The Globalization of Business. London: Routledge.

Dunning, J.H. (ed.) (1999) Governments, Globalization, and International Business. Oxford: Oxford University Press.

Dunning, J.H. (2000) 'The future of the WTO: A socio-relational challenge', Review of International Political Economy 7: 475-483.

Economist (1999) 'The non-governmental order', 11-17 December: 18-19.

Eden, L. (1991) 'Bringing the firm back in: Multinationals in IPE', Millennium: Journal of International Studies 20: 197-224.

Evans, P.B, Jacobson, H.K. and Putnam, R.D. (eds) (1994) Double-edged Diplomacy. Berkeley, CA: University of California Press.

Feigenbaum, H., Henig, J. and Hamnett, C. (1999) Shrinking the State: The Political Underpinnings of Privatization. Cambridge University Press.

Gilpin, Robert (1975) U.S. Power and the Multinational Corporation. New York: Basic Books.

Grosse, R. (1996) 'The bargaining relationship between foreign MNEs and host governments in Latin America', The International Trade Journal 10: 467-99.

Haas, P.M. (1990) Saving the Mediterranean: The Politics of International Environmental Cooperation. New York: Columbia University Press.

Hamel, G. and Prahalad, C.K. (1985) 'Do you really have a global strategy?', Harvard Business Review July-August: 139-148.

Hillman, A. and Keim, G. (1995) 'International variations in the businessgovernment interface: Institutional and organizational considerations', Academy of Management Review 20: 193-214.

Hollway, R. (1998) 'NGOs losing moral high ground?', UN Chronicle 35: 93-94.

Hoskisson, R.E., Eden, L., Lau, C.M. and Wright, M. (2000) 'Strategy in emerging economies', Academy of Management Journal 43: 249-67. 


\section{REVIEW OF INTERNATIONAL POLITICAL ECONOMY}

Hufbauer, D.C., Esty, D.C., Orejas, D., Rubio, L. and Schott, J.J. (2000) NAFTA and the Environment: Seven Years Later. Washington, DC: Institute for International Economics.

Hymer, S.H. (1976) The International Operations of National Firms: A Study of Direct Foreign Investment. Cambridge, MA: MIT Press.

International Monetary Fund/IMF (1998) World Economic Outlook. Washington, D.C. :IMF.

Keck, M.E. and Sikkink, K. (1998) Activists Beyond Borders: Advocacy Networks in International Politics. Cornell University Press.

Kobrin, S.J. (1982) Managing Political Risk Assessment. Berkeley, CA: University of California Press.

Kobrin, S.J. (1991) 'An empirical analysis of the determinants of global integration', Strategic Management Journal 12: 17-31

Kobrin, S.J. (1998) 'The MAI and the clash of globalization', Foreign Policy Fall: 97-109.

Kogut, B. (1985) 'Designing global strategies: Comparative and competitive value added chains', Sloan Management Review 26: 15-28.

Kohut, A. (1999) 'Globalization and the wage gap', The New York Times, 3 December: A 29.

Kohut, A. (2000) 'Web news is pulling in more people, but it's not boosting interest in P. A.', Impact April: 2-3.

Kostova, T. and Zaheer, S. (1999) 'Organizational legitimacy under conditions of complexity', Academy of Management Review 24: 64-81.

Kollman, K. and Prakash, A (2001) 'Green by choice?: Explaining cross-national variations in firm-level responses to EMS-based environmental regimes', World Politics 53: 399-430.

Kolk, A. (2000) The Economics of Environmental Management. Prentice Hall/ Financial Times.

Krugman, P. (1994a) 'Competitiveness: A dangerous obsession', Foreign Affairs 73: $28-45$.

Krugman, P. (ed) (1994b) Strategic Trade Policy and the New International Economics. Cambridge, MA: MIT Press.

Kudrle, R.T. (2000) 'Does globalization sap the fiscal power of the state?', in A. Prakash and J.A. Hart (eds), Coping with Globalization. London: Routledge.

Lawrence, R.Z. (1995) 'Emerging regional arrangements: Building blocks or stumbling blocks?', in J.A. Frieden and D.A. Lake (eds), International Political Economy. New York: St. Martin's Press.

Lenway, S.A. and Murtha, T.P. (1994) 'The state as strategist in international business research,' Journal of International Business Studies, Third Quarter, 513-35.

Lindblom, C. (1977) Politics and Markets. New York: Basic Books.

Lipschutz, R.D. (1992) 'Reconstructing world politics: The emergence of global civil society', Millennium 21: 389-420.

Levy, D.L. and Prakash, A (2001) 'Bargaining old and new: Multinationals in international governance, unpublished draft.

Malhotra, K. (2000) 'NGOs without aid: Beyond the global soup kitchen', Third World Quarterly 21: 655-668.

Makhija, M.V., Kim, K. and Williamson, S.D. (1997) 'Measuring globalization of industries using a national industry approach', Journal of International Business Studies 28: 679-710.

Marcus, A., Kaufman, A. and Beams, D. (eds) (1987) Business Strategy and Public Policy. New York: Quorum Books. 
Marks, G. and McAdam, D. (1996) 'Social movements and the changing structure of political opportunity in the European Union', West European Politics 19: 249-79.

Mathews, J. (1997) 'Power shifts', Foreign Affairs 76: 50-66.

Midford, P. (1993) 'International trade and domestic politics: Improving Rogowski's model of political alignments', International Organization 47: 535-64.

Milner, H.V. (1988) Resisting Protectionism: Global Industries and the Politics of International Trade. Princeton, NJ: Princeton University Press.

Mitchell, R.K., Agle, B.R. and Wood, D.J. (1997) 'Towards a theory of stakeholder salience', Academy of Management Review 22: 853-86.

Mitnick, B.M. (ed.) (1993) Corporate Political Agency. Newbury Park, CA: Sage Publications.

Murtha, T.P. and Lenway, S.A. (1994) 'Country capabilities and the strategic state: How national political institutions affect multinational corporations' strategies', Strategic Management Journal 15: 113-29.

Newport, F. (1999) 'Americans favor China trade agreement, but agree that workers could be hurt', The Gallup Organization, <http://www.gallup.com/ poll/releases/pr991130.asp >; 9 December.

New York Times (1999) 5 September, p. 14.

Nigh, D. (1985) 'The effect of political events on United States direct foreign investment', Journal of International Business Studies 16: 1-17.

North, D.C. (1990) Institutions, Institutional Change, and Economic Performance. New York: Cambridge University Press.

Nua (2000) 'Nua Internet Surveys: How many online?', November 2000, <http:/ / www.nua.net/surveys/how_many_online/index.html>, printed 8July, 2001.

Organization for Economic Cooperation and Development (OECD) (1998) The MAI Negotiating Text (as of 24 April 1998), <http://www.oecd.org//daf/ investment/fdi/mai/maitext.pdf $>$; 24 March.

Ohmae, K. (1991) The Borderless World. New York: Harper.

Olson, M. (1965) The Logic of Collective Action. Harvard, MA: Harvard University Press.

Parker, R.G. (2000) Report from the Bureau of Competition, <http://www.ftc.gov/ speeches/other/rparkerspringaba00.htm>; June 13, 2000.

Pauly, L.W. and Reich, S. (1997) 'National structures and multinational corporate behavior: Enduring differences in the age of globalization', International Organization 51: 1-30.

Pierson, P. (1996) 'The new politics of the welfare state,' World Politics 48: 143-79.

Polanyi. K. (1957 [1944]) The Great Transformation. Boston: Beacon Press.

Porter, M.E. (1990) The Competitive Advantage of Nations. New York: Free Press.

Prahalad, C.K. and Doz, Y.L. (1987) The Multinational Mission: Balancing Local Demands and Global Vision. New York: Free Press.

Prakash, A. (2001) 'The East Asian crisis and the globalization discourse', Review of International Political Economy 8: 119-46.

Prakash, A. and Hart, J.A. (1999) 'Globalization and Governance: An introduction', in A. Prakash and J.A. Hart (eds), Globalization and Governance. London: Routledge.

Prakash, A. and Hart, J.A. (2000) 'Coping with globalization: An introduction', in A. Prakash and J.A. Hart (eds), Coping with Globalization. London: Routledge.

Prebisch, R. (1959) 'Commercial policy in the underdeveloped countries,' American Economic Review: Papers and Proceedings, May: 251-73. 


\section{REVIEW OF INTERNATIONAL POLITICAL ECONOMY}

Preston, L.E. and Windsor, D. (1992) The Rules of the Game in the Global Economy. Boston: Kluwer.

Preston, J. (2000) 'In Mexico, nature lovers merit a kiss from a Whale', New York Times, 5 March: NE.

Putnam, R.D. (1988) 'Diplomacy and domestic politics: The logic of two-level games', International Organization 42: 427--60.

Raghavan, C. (2000) 'After Seattle, world trade system faces uncertain future', Review of International Political Economy 8: 495-504.

Ramamurthi, R. and Vernon, R. (eds) (1991) Privatization and control of state-owned enterprises. Washington, DC: The World Bank.

Reich, R.B (1992) The Works of Nation. New York: Vintage Books.

Rodrik, D. (1997) Has Globalization Gone Too Far? Washington, DC: Institute for International Economics.

Rogowski, R. (1989) Commerce and Coalitions: How Trade Affects Domestic Political Alignments. Princeton, NJ: Princeton University Press.

Rosenau, J.N. (1990) Turbulence in World Politics. Cambridge University Press.

Ruggie, J.G. (1982) 'International regimes, transactions and change: Embedded liberalism in the postwar economic order', International Organization 36: 379-415

Rugman, A.M. and Verbeke, A. (1998a) 'Multinational enterprise and public policy', Journal of International Business Studies 29: 115-36.

Rugman, A.M. and Verbeke, A. (1998b) Corporate strategies and environmental regulations', Strategic Management Journal 19: 363-75.

Rugman, A.M. and D'Cruz, J.R. (2000) Multinationals As Flagship Firms: Regional Business Networks. Oxford: Oxford University Press.

Shaffer, B. (1995) 'Firm-level response to governmental regulations', Journal of Management 21: 495-514.

Sethi, S.P. and Luther, K.A.N. (1986) 'Political risk analysis and direct foreign investment', California Management Review Winter: 57-68.

Simmons, P.J. (1998) 'Learning to live with NGOs', Foreign Policy 112: 82-96.

Spar, D.L. (1999) 'Lost in (cyber)space?', in A.C. Cutler, V. Haufler, and T. Porter (eds), Private Authority and International Affairs. Albany, NY: SUNY Press.

Stigler, G. (1971) 'The theory of economic regulation', Bell Journal of Economics 2: 3-21.

Stopford, J. and Strange, S. (1991) Rival States, Rival Firms. Cambridge University Press.

Strange, S. (1999) 'An international political economy perspective', in J.H. Dunning (ed.), Governments, Globalization, and International Business. New York: Oxford University Press.

Sullivan, D. (1994) 'Measuring the degree of internationalization of a firm', Journal of International Business Studies 25: 325-42.

Then, V. and Walkenhorst, P. (1999) 'Strengthening civil society's capacity to promote democratic governance', in Civil Society at the Millennium, published in cooperation with CIVICUS, Hartford, CT: Kumarian Press, Inc.

United Nations Conference on Trade and Development/UNCTAD (2000) World Investment Report. Geneva: United Nations.

Vernon, R. (1971) Sovereignty at Bay. New York: Basic Books.

Vogel, D. (1978) Lobbying the Corporation. New York: Basic books

Vogel, D. (1995) Trading up. Cambridge, MA: Harvard University Press.

Vogel, S.K. (1998) Freer Markets, More Rules. Ithaca, NY: Cornell University Press. Vogt, Donna U. (2000) Food Safety in the $106^{\text {th }}$ Congress, 7 November, Washington, DC: National Council for Sciecne and the Environment; <http://www.cnie. org/nle/ag-38.html; 3/13/2001>. 
Wallerstein, I. (1979) The Capitalist World Economy. New York: Cambridge University Press.

Wapner, P. (1995) 'Politics beyond state: Environmental activism and world civic politics', World Politics 47: 311-40.

Washington Post (1999) 30 August: A6.

Yoffie, D.B. (ed.) (1994) Beyond Free Trade: Firms, Governments, and Global Competition. Boston, MA: Harvard Business School Press.

Zachary, G.P. (1999) 'Let's play Oligopoly!', Wall Street Journal, 8 March: B1, B10. 